\title{
ЗАСТОСУВАННЯ ІНФОРМАЦІЙНИХ ТЕХНОЛОГІЙ ДЛЯ ОЦІНКИ ОСОБЛИВОСТЕЙ РЕАКТИВНОСТІ ОРГАНІЗМУ МОЛОДИХ ЩУРІВ ПРИ ЕКСПЕРИМЕНТАЛЬНІЙ ГІПОКСІЇ
}

\author{
Н. М. Волкова
}

\author{
ДВНЗ «Тернопільський державний медичний університет \\ імені І. Я. Горбачевського МОЗ України»
}

\begin{abstract}
Дослідження механізмів адаптації молодого організму до таких фракторів як гіпоксичний вплив $є$ актуальною науковою проблемою сьогодення. Метою експерименту було виявлення функціональних наслідків зміни іонної проникності клітинних мембран в асоціативній корі в щурів молодого віку при інкубації в гіпоксичному середовищі за умов зниженого атмосфрерного тиску. Інкубація щурів у гіпоксичному середовищі за умов помірно зниженого атмосферного тиску призводить в асоціативній корі до підвищення проникності клітинних мембран для іонів $\mathrm{Na}^{\circ} \mathrm{i} \mathrm{Cl}^{-}$, що $є$ функціональною ознакою гіпоксичного пошкодження мембранних структур нервової тканини, яке викликає компенсаторне обмеження активності центрального контуру регуляції серцевого ритму і зменшення активності симпатичної регуляції. Особливості реактивності молодих щурів пояснюються незрілістю фронто-таламічної системи мозку.
\end{abstract}

Ключові слова: проникність клітинних мембран, знижений атмосферний тиск, автономна регуляція серцевого ритму.

\section{ПРИМЕНЕНИЕ ИНФОРМАЦИОННЫХ ТЕХНОЛОГИЙ ДЛЯ ОЦЕНКИ ОСОБЕННОСТЕЙ РЕАКТИВНОСТИ ОРГАНИЗМА МОЛОДЫХ КРЫС ПРИ ЭКСПЕРИМЕНТАЛЬНОЙ ГИПОКСИИ}

Н. М. Волкова

\author{
ГВУЗ «Тернопольский государственный медицинский университет \\ имени И. Я. Горбачевского МЗ Украины»
}

\begin{abstract}
Исследование механизмов адаптации молодого организма к таким факторам как гипоксическое воздействие является актуальной научной проблемой современности. Целью эксперимента было выявить функциональные последствия изменения ионной проницаемости клеточных мембран в ассоциативной коре у крыс молодого возраста при инкубации в гипоксической среде в условиях сниженного атмосферного давления. Инкубация крыс в гипоксической среде в условиях умеренно сниженного атмосферного давления приводит в ассоциативной коре к повышению проницаемости клеточных мембран для ионов $\mathrm{Na}+$ и $\mathrm{Cl}^{\prime}$, что является функциональным признаком гипоксического повреждения мембранных структур нервной ткани, что вызывает компенсаторное ограничение активности центрального контура регуляции сердечного ритма и уменьшение активности симпатической регуляции. Особенности реактивности молодых крыс объясняются незрелостью фронто-таламический системы мозга.
\end{abstract}

Ключевые слова: проницаемость клеточных мембран, сниженное атмосферное давление, автономная регуляция сердечного ритма.

\section{THE APPLICATION OF INFORMATION TECHNOLOGIES TO ASSESS THE CHARACTERISTICS OF THE ORGANISM REACTIVITY IN YOUNG RATS IN EXPERIMENTAL HYPOXIA}

N. M. Volkova

SHEI «Ternopil State Medical University by I. Ya. Horbachevsky of MPH of Ukraine»

\begin{abstract}
Research of adaptation mechanisms in young body to factors such as hypoxic effect is an actual scientific problem. The aim of the experiment was to determine the functional consequences of changes in ion permeability of cell membranes in the associative cortex in young rats ufter incubation at hypoxic environment under conditions of low atmospheric pressure. Incubation of rats in the hypoxic environment under conditions of moderately low atmospheric pressure leads to increased

(C) Н. М. Волкова
\end{abstract}


permeability of cell membranes for $\mathrm{Na}+$ and $\mathrm{Cl}$ - ions at the associative cortex. This is a functional feature of hypoxic damage to membrane structures of nerve tissue that causes compensatory limit the activity of the central contour regulation of heart rate and decrease activity of the sympathetic regulation. Peculiarities in reactivity of young rats exist due to the immaturity of fronto-thalamic brain system.

Key words: cell membrane permeability, low pressure autonomous regulation of heart rate.

Вплив зовнішнього середовища $\epsilon$ вагомим фактором розвитку головного мозку [1]. Дослідження механізмів адаптації молодого організму до таких факторів як гіпоксичний вплив $є$ актуальною науковою проблемою сьогодення [2]. У літературі є дані про роль стовбурових структур головного мозку у забезпеченні вікових особливостей реактивності механізмів автономного контролю серцевої діяльності за умов гіпоксичного впливу при обструктивному синдромі апное уві сні [3]. Обговорюються зміни кортико-таламічної взаємодії за умов експериментальної ішемії-реперфузії [4] але обмаль даних про регуляторні впливи з асоціативних ділянок кори великих півкуль на автономну регуляцію серцевого ритму.

Мета дослідження. Метою експерименту було виявити функціональні наслідки зміни іонної проникності клітинних мембран в асоціативній корі в щурів молодого віку при інкубації в гіпоксичному середовищі за умов зниженого атмосферного тиску.

Матеріали і методи дослідження. Експериментальні дослідження проведені на нелінійних молодих щурах обох статей віком 1-1,5 місяці масою 70-100 г. Усі експерименти проведені при метеоситуації I типу, що виключало несприятливий вплив природних змін атмосферних умов. В експериментальній групі (по 20 тварин) реєстрували кардіоінтервалограму до гіпоксії, після гіпоксичного впливу, після трепанації черепа (були окремі групи $з$ правобічною і з лівобічною трепанацією в проекції кіркової ділянки Oc2L), після введення ізотонічного розчину $\mathrm{NaCl}$ через трепанаційний отвір на поверхню кори великих півкуль, із подальшим автоматичним аналізом даних на персональному комп'ютері. У контрольній групі (по 20 тварин) здійснили аналогічний порядок експерименту, за виключенням гіпоксичного впливу. При аналізі результатів кардіоінтервалогафії обраховували середнє значення, стандартне відхилення, варіаційний розкид $(\Delta \mathrm{X})$, моду (Мо), амплітуду моди (АМо), індекс напруження (IH), вегетативний показник ритму (ВПР). Вплив гіпоксичної атмосфери створювали за допомогою зниження тиску на 50,76 гПа (0,05 атм) в апараті Комовського й утримування занаркотизованого щура під скляним дзвоном протягом 1 год.
Усіх тварин утримували на стандартному раціоні віварію. Дослідження виконували відповідно до «Загальних етичних принципів експериментів на тваринах», ухвалених Першим національним конгресом $з$ біоетики (Київ, 2001) та узгоджених 3 положеннями «Європейської конвенції щодо захисту хребетних тварин, які використовуються для експериментальних і інших наукових цілей» (Страсбург, 1986). Комісією з біоетики ДВНЗ «Тернопільський державний медичний університет імені І. Я. Горбачевського МОЗ України» порушень морально-етичних норм при проведенні науководослідної роботи не виявлено.

Результати та їх обговорення. Інкубація молодих тварин у гіпоксичному середовищі призвела до суттєвого збільшення тривалості і варіабельності серцевої діяльності, зменшення амплітуди моди, IH i ВПР. Введення ізотонічного розчину $\mathrm{NaCl}$ через трепанаційний отвір справа вело у інтактних тварин до симпатикотонії. Вважали, що підвищення IH свідчило про зростання напруження регуляторних процесів (табл. 1).

Трепанація не впливала на стан напруження автономної регуляції серцевого ритму.

У молодих щурів введення фізрозчину справа викликало більш значну симпатикотонію, ніж при лівобічному втручанні. У тварин, що піддавалися гіпоксії, інтенсивність включення центральних регуляторних механізмів була меншою, ніж у контрольній групі, що можна характеризувати як пошкоджувальний ефект гіпоксичної атмосфери. Після гіпоксії введення фізрозчину зліва вплинуло у молодих щурів на зменшення варіабельності серцевої діяльності, зменшувались ІН і ВПР (табл. 2). У молодих тварин при атмосферній гіпоксії нами виявлена недостатня активація стреслімітуючих механізмів регуляції серцевого ритму, причиною якої можна вважати незрілість діенцефальних структур мозку. Висока інтенсивність симпатичної регуляції серцевої діяльності у молодих щурів не забезпечує такого ж високого напруження регуляторних процесів, як у дорослих особин. Роль правої і лівої півкуль у забезпеченні фунцціонування центрального контуру регуляції серцевого ритму відрізняється у молодих щурів. 
Таблиця 1. Показники автономної регуляції у молодих щурів з трепанацією справа

\begin{tabular}{|c|c|c|c|c|}
\hline \multirow{2}{*}{\multicolumn{2}{|c|}{ Показник }} & \multicolumn{3}{|c|}{ Група тварин } \\
\hline & & \multirow{2}{*}{$\begin{array}{c}\text { інтактні } \\
0,13 \pm 0,01\end{array}$} & \multirow{2}{*}{$\begin{array}{c}\text { після гіпоксії } \\
- \\
\end{array}$} & \multirow{2}{*}{$\begin{array}{c}\text { після введення фізрозчину } \\
0,13 \pm 0,001\end{array}$} \\
\hline & K & & & \\
\hline $\mathrm{M}, \mathrm{C}$ & $\mathrm{e}$ & $0,13 \pm 0,01$ & $0,19 \pm 0,01$ & $0,18 \pm 0,010 \#$ \\
\hline \multirow{2}{*}{$\Delta \mathrm{X}, \mathrm{c}$} & K & $0,003 \pm 0,001$ & - & $0,002 \pm 0,001$ \\
\hline & $\mathrm{e}$ & $0,003 \pm 0,001$ & $0,005 \pm 0,001$ & $0,003 \pm 0,0001 \mathrm{~d} \#$ \\
\hline \multirow{2}{*}{ Mo, c } & K & $0,13 \pm 0,01$ & - & $0,13 \pm 0,01$ \\
\hline & e & $0,13 \pm 00,01$ & $0,19 \pm 0,01$ & $0,18 \pm 0,01 \mathrm{a} \#$ \\
\hline \multirow{2}{*}{ AMo, $\%$} & K & $48,2 \pm 2,04$ & - & $42,60 \pm 1,15$ \\
\hline & e & $45,3 \pm 3,78$ & $32,9 \pm 3,70$ & $41,4 \pm 7,01=0$ \\
\hline \multirow{2}{*}{ IH, ум. од. } & K & $40955,60 \pm 72,24$ & - & $77421,71 \pm 63,57$ \\
\hline & $\mathrm{e}$ & $39885,752 \pm 52,68$ & $16131,46 \pm 72,40$ & $31036,80 \pm 856,56=a \#$ \\
\hline \multirow{2}{*}{ ВПР, ум. од. } & K & $1941,585 \pm 8,672$ & - & $2224,313 \pm 24,670$ \\
\hline & $\mathrm{e}$ & $2082,75 \pm 27,66$ & $977,67 \pm 29,48$ & $1492,48 \pm 232,42=\#$ \\
\hline
\end{tabular}

Примітки:

1. $-\mathrm{p}<0,05$ порівняно з інтактними тваринами;

2. $\neq-\mathrm{p}<0,05$ порівняно з ефектом гіпоксичного впливу;

3. $\square-\mathrm{p}<0,05$ порівняно з лівостороннім ефектом;

4. к - контрольна група тварин, які не піддавалися гіпоксії;

5. е - експериментальна група тварин, які отримали гіпоксичний вплив;

6. \# - $<<0,05$ порівняно з контрольною групою.

Таблиця 2. Показники автономної регуляції у молодих щурів з трепанацією зліва

\begin{tabular}{|c|c|c|c|c|}
\hline \multirow{2}{*}{\multicolumn{2}{|c|}{ Показник }} & \multicolumn{3}{|c|}{ Група тварин } \\
\hline & & \multirow{2}{*}{$\begin{array}{c}\text { інтактні } \\
0,13 \pm 0,01\end{array}$} & \multirow{2}{*}{$\begin{array}{c}\text { після гіпоксії } \\
-\end{array}$} & \multirow{2}{*}{$\frac{\text { після введення фізрозчину }}{0,13 \pm 0,01}$} \\
\hline$M$ & $\mathrm{~K}$ & & & \\
\hline $\mathrm{M}, \mathrm{C}$ & e & $0,13 \pm 0,01$ & $0,23 \pm 0,01 \star$ & $0,20 \pm 0,01 \star \#$ \\
\hline \multirow{2}{*}{$\Delta \mathrm{X}, \mathrm{c}$} & K & $0,003 \pm 0,001$ & - & $0,004 \pm 0,001$ \\
\hline & e & $0,003 \pm 0,001$ & $0,001 \pm 0001$ & $0,006 \pm 0,001$ \# \\
\hline \multirow{2}{*}{ Mo, c } & K & $0,13 \pm 0,01$ & - & $0,13 \pm 0,01$ \\
\hline & $\mathrm{e}$ & $0,13 \pm 00,01$ & $0,23 \pm 0,01$ & $0,20 \pm 0,01 \#$ \\
\hline \multirow{2}{*}{ AMo, $\%$} & K & $48,2 \pm 2,04$ & - & $37,5 \pm 5,50$ \\
\hline & $\mathrm{e}$ & $45,3 \pm 3,78$ & $34,0 \pm 3,0$ & $23,5 \pm 0,52=$ \\
\hline \multirow{2}{*}{ IH, ум. од. } & $\mathrm{K}$ & $40955,60 \pm 72,24$ & - & $10421,58 \pm 11,25$ \\
\hline & $\mathrm{e}$ & $39885,752 \pm 52,68$ & $9908,97 \pm 323,32$ & $9629,63 \pm 70,37 \star$ \\
\hline \multirow{2}{*}{ ВПР, ум. од. } & $\mathrm{K}$ & $1941,585 \pm 8,672$ & - & $672,49 \pm 47,57$ \\
\hline & e & $2082,75 \pm 27,66$ & $585,76 \pm 32,67$ & $819,24 \pm 14,09 \neq=$ \\
\hline
\end{tabular}

Примітки:

1. - $<<0,05$ порівняно з інтактними тваринами;

2. $\neq-\mathrm{p}<0,05$ порівняно з ефектом гіпоксичного впливу;

3. к - контрольна група тварин, які не піддавалися гіпоксії;

4. е - експериментальна група тварин, які отримали гіпоксичний вплив;

5. \# - $\mathrm{p}<0,05$ порівняно 3 контрольною групою.

За даними літератури [5], у молодих тварин спостерігається висока реактивність і пластичність регуляторних механізмів у разі дії стресових чинників. У літературі активацію симпатичної регуляції при гіпоксичному впливі пов'язують iз закриттям калієвих каналів у периферійних збудливих клітинах, чутливих до зниження вмісту кисню і надлишку іонів водню у навколоклітинному середовищі [6]. У літературі є дані про зміну активності потенціалозалежних іонних каналів, участі позаклітинного натрію в регуляції іонного транспорту в нейронах при гіпоксії [7]. Показано, що гіпоксичний вплив призводить до суттєвого порушення таламо-кортикальних взаємовідно- 
син, що має наслідком порушення опрацювання сенсорної інформації і може робити внесок у розвиток кіркової патології і поведінкових відхилень у подальшому житті [4].

Таким чином, навіть у разі помірного гіпоксичного впливу в молодому організмі, важливими засобами нормалізації автономного контролю серцевої діяльнсті є чинники, які забезпечують відновлення функціонального стану і метаболічних резервів нейронів кори великих півкуль. Оптимальне метаболічне забезпечення асоціативної кори дозволяє виконувати інтегративну діяльність через участь у гомеостатичних регуляторних механізмах.

\section{Література}

1. Kolb B. Brain Plasticity and Behaviour in the Developing Brain / B. Kolb, R. Gibb // J. Can Acad Child Adolesc Psychiatry. - 2011. - № 20 (4). - P. 265-276.

2. Регуляторная роль митохондриальной дисфункции при гипоксии и ее взаимодействие с транскрипционной активностью / Л. Д. Лукьянова, А. М. Дудченко, Т. А. Цыбина, Э. Л. Германова // Вестник Российской AMH. - 2007. - № 2. - C. 3-13.

3. Daniel B. Zoccal Sympathetic-mediated hypertension of awake juvenile rats submitted to chronic intermittent hypoxia is not linked to baroreflex dysfunction / Daniel B. Zoccal, Leni G. H. Bonagamba1, Julian F. R. Paton, Benedito H. Machado // Exp. Physiol. - 2009. - № 94.9. - P. 972-983.

4. Thalamocortical Dysfunction and Thalamic Injury after Asphyxial Cardiac Arrest in Developing Rats / M. Shoykhet,
Висновки. Інкубація щурів у гіпоксичному середовищі за умов помірно зниженого атмосферного тиску призводить в асоціативній корі до підвищення проникності клітинних мембран для іонів $\mathrm{Na}+\mathrm{i} \mathrm{Cl}$, що є функціональною ознакою гіпоксичного пошкодження мембранних структур нервової тканини, яке викликає компенсаторне обмеження активності центрального контуру регуляції серцевого ритму і зменшення активності симпатичної регуляції. Особливості реактивності молодих щурів пояснюються незрілістю фронтоталамічної системи мозку.

D. J. Simons, H. Alexander [et al.] // J. Neurosci. - 2012. - № 32 (14). - P. 4972-4981.

5. Кутіков О. Є. Особливості реактивності тварин різного віку на емоційно-больовий стрес як показник якості адаптивної поведінки / О. Є. Кутіков // Журнал психиатрии и медицинской психологии. - 2004. - № 4 (14). - C. 163-165.

6. Molecular physiology of oxygen-sensitive potassium channels / A. J. Patel, E. Honore'// Eur. Respir. J. - 2001. - Vol. 18, № 1. - P. 221-227.

7. Зміна проникності протонактивованих каналів до іонів натрію та кальцію під дією антиоксиданта / А. Л. Федоренко, Н. О. Лозова, Т. М. Волкова, О. О. Кришталь // Нейрофізіологія. - 2006. - Т. 3, № 38. - C. 193-197. 